\title{
Successful Treatment in a Newborn Infant with Chylous Ascites and Chylous Hydrocele
}

\author{
Sang Hyun Ahn, MD, Won Duck Kim, MD, and Young Jin Kim, MD \\ Department of Pediatrics, Daegu Fatima Hospital, Daegu, Korea
}

\section{ABSTRACT}

Chyle only occurs in the peritoneal cavity or around the pericardium through damage to the lymph nodes or improper drainage of the lymph and is characterized by a colostrum-like color and being rich in triglyceride. We encountered a case of a newborn infant with abdominal distention and further diagnosed chylous ascites and hydrocele by inspecting and analyzing the fluid obtained from the abdominal cavity and scrotum. Additionally, a lymphoscintigraphy was performed, which showed a decrease in the uptake of radioactive isotopes in the left iliac nodes and a delayed appearance. Here, we report a case of chyle diagnosed through puncture analysis and its subsequent successful treatment.

Key Words: Chylous hydrocele; Lymphoscintigraphy; Congenital lymphatic dysplasia

서론

유미 삼출증은 유미(chyle)가 흥강, 복강, 음낭 등에 누출되는 질환을 말한다 ${ }^{1,2)}$. 유미가 복 강 내로 유출되는 원인은 선천성 림프관 기형, 수술에 의한 림프관 손상, 외상, 간경화, 복막 띠 (peritoneal band), 전신 림프관종, 창자의 만성 염증, 미코플라스마로 감염, 종양 등이 있다 ${ }^{3-5)}$. 유미 복수의 주요 증상은 무른 변과 함께 빠르게 진행하는 복부팽만이 특징이며 사지 부종과 체 중증가 지연이 흔히 동반되며, 심할 경우 음낭부종, 서혜부 및 배꼽 탈장, 호흡 곤란까지도 나타 날 수 있다 ${ }^{2,4,6)}$. 합병증을 예방하기 위해서는 조기 진단이 중요하나 신생아 및 영아에서는 증상 이 뚜렷하지 않아 진단이 쉽지 않다. 진단은 지방 식이 후 복수 천자를 통해 유미액의 육안적 관 찰 및 구성 성분의 특성을 확인하여야 한다 ${ }^{1,27)}$. 이러한 특징들을 바탕으로 비정상적인 림프계를 확인하는 림프신티그라피(lymphoscintigraphy), 림프관 조영술(lymphangiography) 등의 영상 검사를 시행할 수 있다 ${ }^{8,9}$. 유미 삼출증의 치료는 보존적 치료를 우선적으로 시행하면서 유미 배 액 및 약물 사용 등을 추가할 수 있다 ${ }^{10-12)}$. 본 저자들은 음낭수종(hydrocele)과 복부팽만을 보인 신생아에서 흡인액의 화학적 분석과 림프신티그래피를 통해 유미 삼출증으로 진단하고 성공적 인 치료를 한 1례를 경험하였기에 보고하는 바이다.
Received: 10 April 2019

Revised: 19 July 2019

Accepted: 9 August 2019

Correspondence to: Won Duck Kim, MD

Department of Pediatrics, Daegu Fatima Hospital, 99 Ayang-ro, Dong-gu, Daegu 41199, Korea

Tel: +82-53-940-7244

Fax: +82-53-954-7417

E-mail: 0101turtle@gmail.com

Copyright(c)

By Korean Society of Neonatology.

All right reserved.

This is an Open-Access article distributed under the terms of the Creative Commons Attribution Non-Commercial License (http://creativecommons.org/licenses/ by-nc/4.0), which permits unrestricted non-commercial use, distribution, and reproduction in any medium, provided the original work is properly cited. 


\section{증례}

산과력 1-0-0-1인 36세 산모로부터 임신나이 38주 2일에 자연분 만을 통해 3,230 g (75-90 percentile)으로 출생한 남아였다. 산모는 임신 중 특별한 약물력이나 기저질환이 없었고 정기적인 산전 진찰 을 받았다. 출생 직후 시행 된 신체검사에서 경한 음낭부종 외 특이 소견이 관찰되지 않았다. 이후 조리원에서 지내던 중 출생 11 일째 $38^{\circ} \mathrm{C}$ 이상의 발열이 발생하였으며 이전보다 음낭부종이 더욱 심해 져 본원으로 전원 되었다.

본원 도착 당시 생체징후는 혈압 $90 / 58 \mathrm{~mm} \mathrm{Hg}$, 맥박 160 회/분, 체온 $36.8^{\circ} \mathrm{C}$, 산소 포화도는 $100 \%$ 로 측정되었다. 환아는 음낭부종
외 복부팽만이 관찰되었으며 평소보다 많이 보채는 증상이 있었다 (Figure 1). 혈액 검사상 혈색소 $15.0 \mathrm{~g} / \mathrm{dL}$, 적혈구 용적률 $39.7 \%$, 백

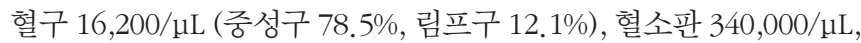
아스파르테이트아미노전달효소 $31 \mathrm{U} / \mathrm{L}$, 알라닌아미노전달효소 14 $\mathrm{U} / \mathrm{L}$, 총 빌리루빈 $5.93 \mathrm{mg} / \mathrm{dL}$, 총 단백질 $5.4 \mathrm{~g} / \mathrm{dL}$, 알부민 $3.3 \mathrm{~g} / \mathrm{dL}$, C -반응단백질 $3.42 \mathrm{mg} / \mathrm{dL}$ (정상, 0- $0.5 \mathrm{mg} / \mathrm{dL}$ )으로 나타났다. 전 해질 및 소변검사는 정상이었다. 음낭 초음파에서 양측 고환(testis) 의 크기 및 혈류 흐름(vascularity)은 정상이었으며 음낭수종만 관찰 되었다. 하지만 초음파 검사 후에도 음낭부종 및 보채는 증상이 악 화되어 입원 당일에 외과 협진 하에 음낭천자를 시행하였다. 천자 를 통해 흡인한 액체는 육안적 관찰을 통해 초유로 판단하고 이에
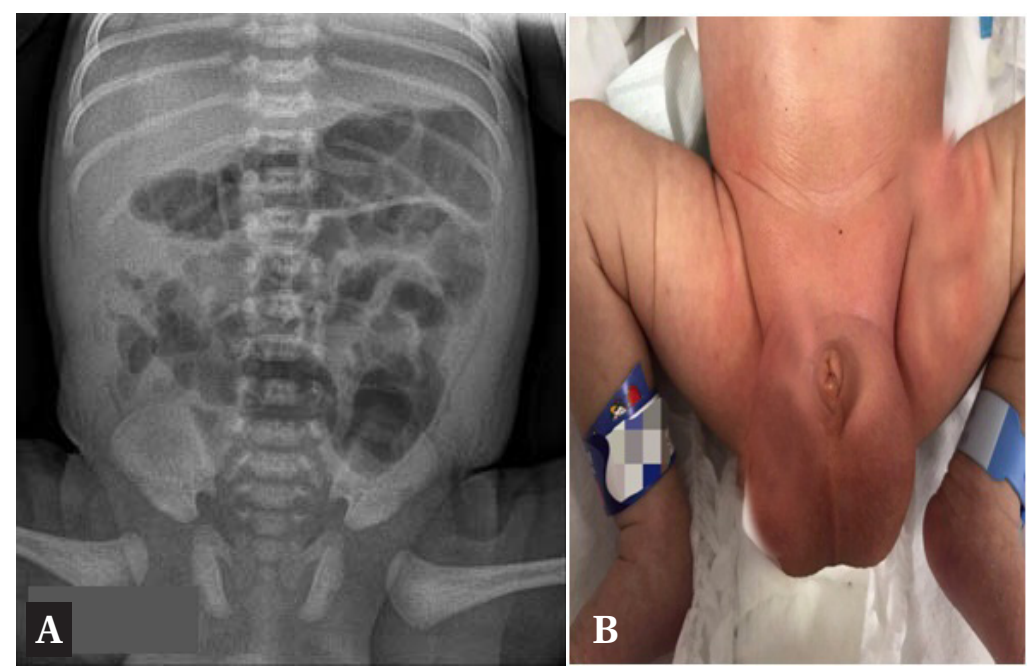

Figure 1. Photo of the scrotum after centesis. (A) Abdominal supine X-ray shows gas-filled small and large bowel loops with dilatation. (B) Scrotal swelling and abdominal distension are observed.

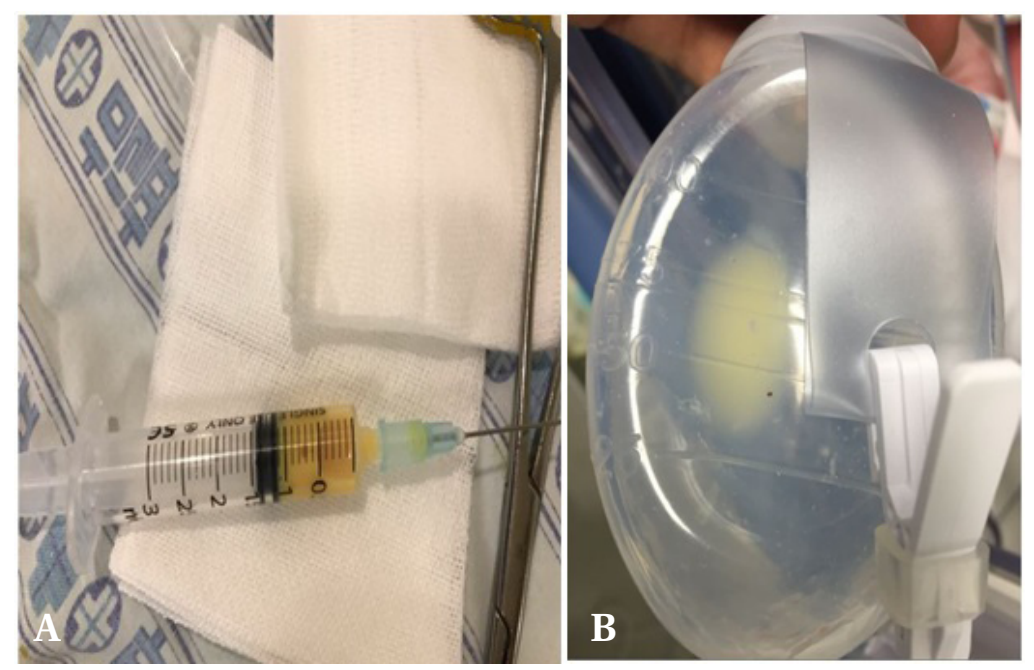

Figure 2. Photo of the body fluid. (A) Fluid obtained from the scrotal centesis. It appears yellowish and turbid, similar to colostrum. (B) Chyle emerges into the drain tube during conservative treatment. 
서혜부 탈장이나 장염전 등을 의심하여 응급 개복술을 시행하였다 (Figure 2). 응급 개복술에서 환아의 전반적인 장의 상태는 양호하 였으며 탈장이나 탈장낭 등은 관찰되지 않았다. 하지만 복강 내에 서 음낭천자 때와 같은 색의 복수를 $5 \mathrm{cc}$ 흡인하였으며 배액관을 복 강에 거치하였다. 흡인액의 화학적 분석에서 중성지방이 $1,076 \mathrm{mg} /$ $\mathrm{dL}$, 림프구 비율이 $70 \%$ 이상이었다(Table 1). 흡인액의 육안적 소견 및 화학적 분석을 통해 음낭 및 복강 내에 발생한 유미 삼출증으로 진단하였다.

이후 환아에게 금식 및 총정맥 영양 등 보존적 치료를 시행하였으 며 배액관을 통해 유미의 양을 추적하였다. 보존적 치료 및 배액 시

Table 1. Analysis of Body Fluid

\begin{tabular}{lcccc}
\hline \multirow{2}{*}{ Body fluid } & Scrotal fluid & & \multicolumn{2}{c}{ Ascites } \\
\cline { 2 - 3 } \cline { 5 - 5 } & HD\#1 (NPO) & & HD\#17 (NPO) & HD\#22 (NPO) \\
\hline TG (mg/dL) & 1,076 & & 14 & 118 \\
TP (mg/dL) & & & 3.0 & 3.6 \\
Color & Yellow & & Yellow & Yellow \\
Turbidity & Turbid & & Turbid & Turbid \\
RBC $(/ \mu \mathrm{L})$ & $0-2$ & & $2-5$ & \\
WBC $(/ \mu \mathrm{L})$ & 2,350 & & 3,250 & \\
Lymphocyte $(\%)$ & 70 & & 80 & $(-)$ \\
Culture & $(-)$ & $(-)$ & \\
\hline
\end{tabular}

Abbreviations: HD, hospital day; NPO, nil per os; TG, triglyceride; TP, total protein; RBC, red blood cell; WBC, white blood cell.
행 후 복부팽만 및 음낭부종이 감소하기 시작하였으며 생후 25일째 배액양이 하루 $20 \mathrm{cc}$ 정도로 유지되었다. 추가적인 유미 배액양 감 소를 위해 생후 25일째부터는 소마토스타틴(octerotide) $1 \mu \mathrm{g} / \mathrm{kg} / \mathrm{hr}$ 를 정맥 투여하였다. 주입 후에도 배액양은 크게 줄지 않아 $2 \mu \mathrm{g} / \mathrm{kg} /$ $\mathrm{hr}$ 로 증량하였으며 증량 후 3 일째부터는 배액양이 줄어 일주일 후에 는 $6 \mathrm{cc}$ 까지 감소되었다. 배액양은 감소하였으나 오랜 금식으로 인 해 생후 32 일째부터 체중이 $3,900 \mathrm{~g}$ 으로 정체되었다. 이에 총 정맥 영양을 유지하면서 쌀미음을 경구 식이로 시작하였다. 경구 식이 후 배액양 증가 및 구토 등의 부작용이 없어 이틀째부터는 중간사슬중 성지방(medium chain triglyceride, MCT) 분유를 절반으로 희석하여 3 시간마다 $30 \mathrm{cc}$ 씩 추가하였다. MCT 분유 추가 후 이틀째 환아 배액 양이 $13 \mathrm{cc}$ 로 다소 증가하였으나 이후 지속적으로 감소하여 수유를 지속하였다.

환아의 상태가 안정된 후 유미 삼출증의 원인을 찾기 위해 림프신 티그래피를 시행하였다(Figure 3). 방사선 동위 원소는 양쪽 다리 림 프관을 통해 잘 주입되었다. 이후 24시간 지연 영상에서 뚜렷하게 누출되는 부위는 보이지 않았으나 왼쪽 다리 결절(left iliac node)에 서 섭취가 감소하는 소견이 관찰되었다. 이를 토대로 음낭 및 복강 에 발생한 유미 삼출증의 원인이 왼쪽 다리 결절 림프관 기형에 따른 것으로 최종 진단하였다. 이후 배액관은 유지한 채 쌀미음 및 MCT 분유, 소마토스타틴 주입, 정맥 영양 공급 등을 지속하였으며 생후 47 일째부터는 유미가 더 이상 배액 되지 않으며 체중도 안정적으로 증가하였다. 또한 초음파 추적검사에서도 이전보다 음낭부종이 많

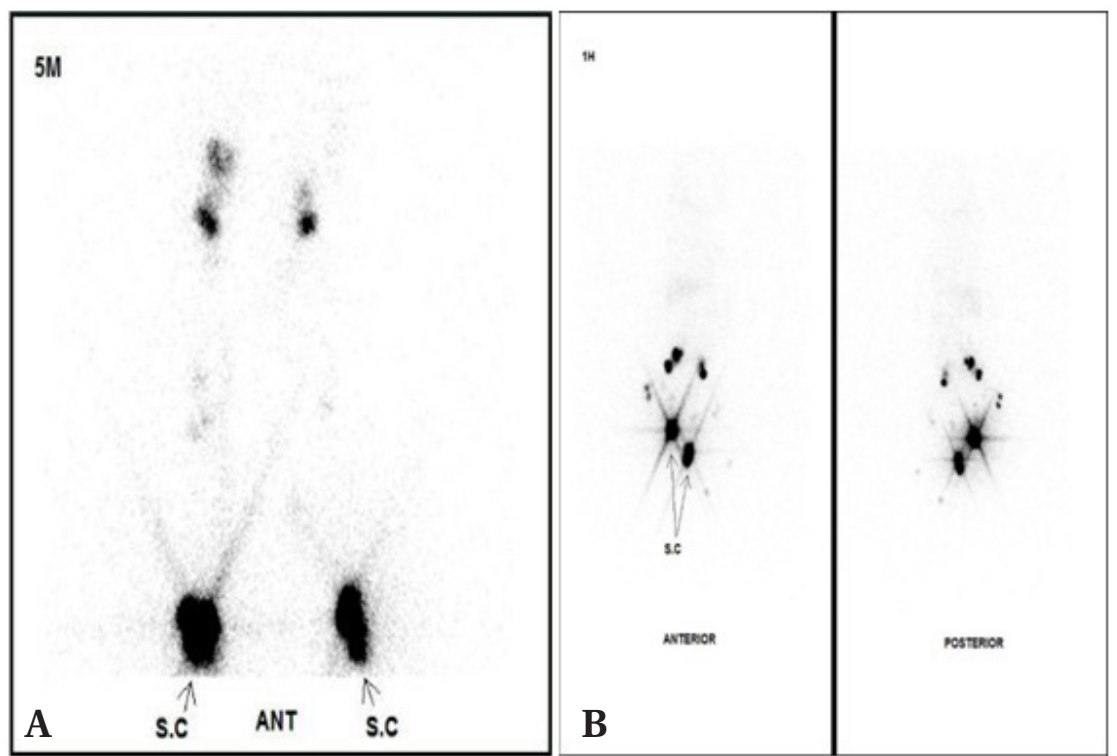

Figure 3. Results of the lymphoscintigraphy. (A) Photo obtained immediately after the injection of radioactive isotopes. The bilateral leg lymphatic flow is normal, and bilateral inguinal lymph nodes are symmetrically well-observed. (B) Photo obtained 24 hours after the injection of radioactive isotopes. It appears that the uptake of these isotopes has decreased in the left iliac nodes. Abbreviations: S.C, subcutaneous; ANT, anterior. 
이 줄어들었으며 복수도 관찰되지 않아 생후 50 일째 소마토스타틴 을 중지하고 배액관 제거 후 퇴원하였다. 퇴원 후에도 MCT 분유를 지속하였고 복부팽만 및 음낭부종이 나타나지 않아 생후 100 일째부 터는 일반 분유로 바꿔 수유하였다. 환아는 외래에서 추적 관찰 중 이며 특이 소견 없이 정상적인 성장과 발달을 보이고 있다.

\section{고찰}

본 증례는 음낭수종 및 복부팽만을 가진 환아에게서 천자흡인술 과 화학적 분석을 통해 유미 삼출증을 진단하였고 림프신티그래프 를 통한 선천성 림프관 이형성증이 원인임을 확인하고 치료한 국내 첫 사례이다. 유미 삼출증의 유병률은 약 2 만 명 당 1 명꼴로 매우 낮 으나 전 연령에서 발생할 수 있는 것이 특징이다 ${ }^{2,3)}$. 원인으로는 림 프관 기형, 외상, 전신 림프관종 등이 있고 ${ }^{3-5)}$ 그 중에서도 림프관 퇴 행 과정의 실패로 인한 선천성 림프관 기형이 가장 흔하달. 이러한 유미 삼출증은 일반적으로 복강 및 흥강에서 주로 나타나며 유미 복 수 및 유미흥으로 진단된다. 유미 복수의 국내 사례는 총 5례로 이 중 1 례만이 음낭수종을 동반하였으나 화학적 분석은 시행하지 않았 다 $^{13)}$.

유미는 혈장과 비슷한 농도의 단백질과 전해질을 가지나 중성지 방이 높고 킬로미크론(chylomicron)이 존재하는 것이 특징이다. 초 유와 같은 특징적인 색깔을 띠어 육안으로도 쉽게 의심할 수 있으나 결핵, 만성적 흥막 감염 및 장염전에 의해 발생하는 가성유미, 농양 등과 반드시 감별해야 한다. 따라서 반드시 육안적 확인과 화학적 분석이 함께 시행되어야 한다. 또한 비정상적인 유미 삼출이 존재한 다면 림프절과 림프관 이상을 확인하는 림프신티그라피, 림프관 조 영술 등의 영상검사가 추가적으로 고려되어야 한다 ${ }^{8,9)}$. 림프관 조영 술은 최소 침습적인 방법을 통해 시술 이후 침상 옆에서 추적 관찰이 가능하여 위중한 상태의 환자에게도 적용할 수 있다는 장점이 있다. 하지만 조영제 주입을 통한 염증반응 등의 부작용으로 인해 신생아 에서 증례 보고가 많지 않다. 이에 비해 림프신티그라피는 방사선 동의원소를 이용하여 림프절 기형 및 손상을 보다 정확하게 파악할 수 있으며 조영제에 관한 부작용이 없는 이점이 있다. 이로 인해 신 생아나 영아에서 선천성 림프관 이형성증, 림프관 손상을 파악하는 데 유용한 방법으로 알려져 있다 ${ }^{14)}$. 본 증례에서도 림프신티그라피 시행하여 선천성 림프관 이상을 확인하였다.

치료는 유미 삼출로 인한 각종 합병증을 막기 위해 배액관 삽입 과 금식 그리고 경정맥 영양 등을 우선적으로 시행하여야 한다. 이 후 배액양 감소 및 경구 식이가 가능해지면 일반 분유가 아닌 장에서 림프관을 통하지 않고 직접 문맥으로 흡수되는 MCT 분유를 고려해 야 한다. 또한 복부 내장 혈류를 줄여 유미의 생성을 감소시키는 소 마토스타틴을 사용할 수 있다 ${ }^{9-11)}$. 유미 삼출증 치료에서 소마토스
타틴의 사용은 신생아의 경우 2003년 $\mathrm{Au}$ 등 ${ }^{15)}$ 에 의해 처음 발표되었 으며 대부분 정맥 내 주입으로 사용 용량은 0.8-10 $\mu \mathrm{g} / \mathrm{kg} / \mathrm{hr}$ 로 5-20 일가량 치료한다. 부작용으로는 구토, 설사, 지방변, 복부팽만 및 간 기능 장애 등이 보고된다 ${ }^{16)}$. 따라서 이러한 부작용에 유의하여 주입 및 증량이 필요하다. 본 증례에서도 소마토스타틴을 사용하였으며 $\mathrm{MCT}$ 분유와 쌀미음을 수유하여 지속적인 유미 배액양 감소 및 증상 이 호전되었다. 하지만 이러한 보존적 치료가 실패할 경우 수술적 치료를 시행할 수 있다. . 수술적 치료로는 흥관결찰술(thoracic duct ligation)이나 흥강유착술(pleurodesis) 등이 있다. 선천성 림프관 이 형성증의 예후는 대체로 불량하다고 보고되고 있으나 ${ }^{3,9)}$ 기저질환이 나 산전 진찰, 유전적 이상 유무 그리고 유미 삼출증의 발생 부위 등 에 따라 예후는 다양할 것으로 생각된다 ${ }^{17)}$. 환아의 경우 음낭 부위에 서 주로 발생하였지만, 기저질환 등이 동반되지 않아 예후가 좋았던 것으로 생각된다. 본 증례에서는 시행되지 않았지만 선천성 림프관 이형성증에서 림프계 발달에 영향을 주는 유전자 이상(다운증후군, 에드워드 증후군 등) 여부에 대한 연구가 치료 및 예후 결정을 위해 활발히 이루어져야 할 것으로 보인다 ${ }^{18)}$. 저자들은 유미 삼출증이 복 부 뿐만 아니라 음낭에서도 발생된 환아를 경험하였고 성공적인 진 단 및 치료를 하였기에 보고하는 바이다.

\section{ARTICLE INFORMATION}

\section{Ethical statement}

This study was approved by the Institutional Review Board of Daegu Fatima Hospital (DFEORIO053). Written informed consent was obtained from the patient's father.

\section{Conflicts of interest}

No potential conflict of interest relevant to this article was reported.

\section{Author contributions}

Conception or design: S.H.A., W.D.K.

Acquisition, analysis, or interpretation of data: S.H.A., W.D.K., Y.J.K.

Drafting the work or revising: S.H.A.

Final approval of the manuscript: W.D.K., Y.J.K.

\section{ORCID}

Sang Hyun Ahn https://orcid.org/0000-0002-1787-6944

Young Jin Kim https://orcid.org/0000-0001-8276-0473 


\section{Acknowledgments}

None

\section{REFERENCES}

1. Cardenas A, Chopra S. Chylous ascites. Am J Gastroenterol 2002;97:1896-900.

2. Press OW, Press NO, Kaufman SD. Evaluation and management of chylous ascites. Ann Intern Med 1982;96:358-64.

3. Smeltzer DM, Stickler GB, Fleming RE. Primary lymphatic dysplasia in children: chylothorax, chylous ascites, and generalized lymphatic dysplasia. Eur J Pediatr 1986;145:286-92.

4. Browse NL, Wilson NM, Russo F, al-Hassan H, Allen DR. Aetiology and treatment of chylous ascites. Br J Surg 1992;79:114550.

5. Steinemann DC, Dindo D, Clavien PA, Nocito A. Atraumatic chylous ascites: systematic review on symptoms and causes. J Am Coll Surg 2011;212:899-905.

6. Aalami OO, Allen DB, Organ CH Jr. Chylous ascites: a collective review. Surgery 2000;128:761-78.

7. Runyon BA, Akriviadis EA, Keyser AJ. The opacity of portal hypertension-related ascites correlates with the fluid's triglyceride concentration. Am J Clin Pathol 1991;96:142-3.

8. Witte CL, Witte MH, Unger EC, Williams WH, Bernas MJ, McNeill GC, et al. Advances in imaging of lymph flow disorders. Radiographics 2000;20:1697-719.

9. Bengtsson BOS. Neonatal lymphatic (chylous) disorders. Neoreviews 2013;14:e600-12.
10. Uriz J, Cardenas A, Arroyo V. Pathophysiology, diagnosis and treatment of ascites in cirrhosis. Baillieres Best Pract Res Clin Gastroenterol 2000;14:927-43.

11. Weinstein LD, Scanlon GT, Hersh T. Chylous ascites: management with medium-chain triglycerides and exacerbation by lymphangiography. Am J Dig Dis 1969;14:500-9.

12. Ohri SK, Patel T, Desa LA, Spencer J. The management of postoperative chylous ascites: a case report and literature review. J Clin Gastroenterol 1990;12:693-7.

13. Kim J, Hong YJ, Cho HH, Shim SY, Park EA, Cho SJ. Ileal atresia presenting with massive chylous ascites and hydrocele in a newborn. Perinatology 2017;28:69-73.

14. Shibasaki J, Hara H, Mihara M, Adachi S, Uchida Y, Itani Y. Evaluation of lymphatic dysplasia in patients with congenital pleural effusion and ascites using indocyanine green lymphography. J Pediatr 2014;164:1116-20.

15. Au M, Weber TR, Fleming RE. Successful use of somatostatin in a case of neonatal chylothorax. J Pediatr Surg 2003;38:1106-7.

16. Huang Y, Zhuang S, Li Y, Liu M, Chen H, Du M. Successful management of congenital chylous ascites in a premature infant using somatostatin analogue. Indian J Pediatr 2011;78:3457.

17. Weniger M, D'Haese JG, Angele MK, Kleespies A, Werner J, Hartwig W. Treatment options for chylous ascites after major abdominal surgery: a systematic review. Am J Surg 2016;211: 206-13.

18. Yoon YM, Kim SN, Kim HR, Jung YH, Choi CW, Kim BI. A case of congenital lymphatic dysplasia complicated by hydrops fetalis. Neonatal Med 2017;24:40-4. 